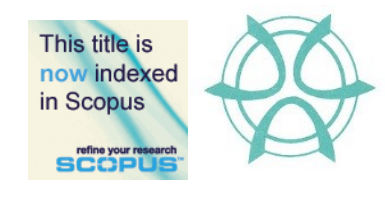

PLANNING MALAYSIA:

Journal of the Malaysian Institute of Planners

VOLUME 18 ISSUE 1 (2020), Page $1-10$

\title{
ATTITUDES AND PRO-ENVIRONMENTAL BEHAVIOURS: DETERMINING FACTOR OF PERSONALITY AND LIFESTYLE
}

\author{
Aisyah Abu Bakar', Mariana Mohamed Osman² \& Mizan Hitam ${ }^{3}$ \\ ${ }^{1,2}$ Kulliyyah of Architecture and Environmental Design \\ INTERNATIONAL ISLAMIC UNIVERSITY MALAYSIA \\ ${ }^{3}$ Faculty of Architecture, Panning and Surveying \\ UNIVERSITI TEKNOLOGI MARA
}

\begin{abstract}
Sustainability in well-being embodies the interconnecting course of how various systems influence each other. The more strongly individuals subscribe to values beyond their immediate interests, that is, prosocial, collectivistic and biospheric values, the more likely they are to engage in environmental behaviour. Issue: Existing research has limited evidence on specific values of Malaysian's personality and lifestyle (PL) that have significant impact on attitude and proenvironmental behaviour (AP). Purpose: This paper aims to verify the statistical predictability of AP based on PL. Approach: Multiple Correlation and Multiple Linear Regression were carried out to assess linear associations and parameters of linear equations to predict AP components based on PL items. Findings: AP components were moderately predictable by some of the PL items. Specifically, 'Urging media to raise environmental awareness' and 'being mindful about environmental destruction' were the two strongest predictors of AP.
\end{abstract}

Keywords: attitude and pro-environmental behaviour, personality and lifestyle 
Aisyah Abu Bakar, Mariana Mohamed Osman, Mizan Hitam

Attitudes and Pro-Environmental Behaviours: Determining Factor of Personality and Lifestyle

\section{INTRODUCTION}

Human interdependence with the environment (HIE) is a valuable aspect of architectural psychology as it is an extended understanding towards improving the well-being aspects of architecture. HIE is one of the main causes of subjective sustainable well-being (SSWB). Personality and lifestyle (PL) and attitude and pro-environmental behaviours (AP) are interrelated dimensions of HIE (Abu Bakar et al., 2017a, 2017b, 2017c, 2018), yet the impact of specific PL items on AP has limited proofs. This paper assesses the statistical predictability of AP based on PL items of Malaysian respondents.

\section{LITERATURE REVIEW}

Case studies based on articles from selected Asian Journals from the year 2011 onwards highlight conditional factors and potential determinants of Interaction with Nature (AP). Table 1 summarizes these findings.

Table 1 Conditional Factors and Potential Determinants for Environmental Behaviour

\begin{tabular}{|c|c|c|}
\hline Conditional Factors & Potential Determinants & References \\
\hline $\begin{array}{l}\text { Cultural orientations - consumers with high } \\
\text { collectivistic values and low materialistic } \\
\text { values had higher recycling tendency }\end{array}$ & $\begin{array}{l}\text { Recycling attitude and behaviours } \\
\text { (the approach to reclaiming the } \\
\text { purpose of used materials) }\end{array}$ & $\begin{array}{l}\text { (Latif \& Omar, } \\
\text { 2012) }\end{array}$ \\
\hline $\begin{array}{l}\text { Policies implementation supporting } \\
\text { environmental purchasing behaviours such as } \\
\text { promotion of energy rating, labelling green } \\
\text { appliances, banning hazardous items, rebate, } \\
\text { and green procurement practices }\end{array}$ & $\begin{array}{l}\text { Purchase energy-efficient, } \\
\text { recycled packaging, and } \\
\text { biodegradable products, and green } \\
\text { detergents }\end{array}$ & $\begin{array}{l}\text { (Harizan et al., } \\
\text { 2013) }\end{array}$ \\
\hline $\begin{array}{l}\text { Concerns about environment, social influence, } \\
\text { accessibility to environmental facilities, } \\
\text { monetary motivation, and altruism. }\end{array}$ & $\begin{array}{l}\text { Waste separation, practising buy- } \\
\text { back centres and recycling and } \\
\text { reusing household items }\end{array}$ & (Zena et al., 2014) \\
\hline $\begin{array}{l}\text { High income and education level favour the } \\
\text { green movement and have concerns for food } \\
\text { safety }\end{array}$ & $\begin{array}{l}\text { Purchasing and consuming } \\
\text { organic food }\end{array}$ & (Teng et al., 2011) \\
\hline $\begin{array}{l}\text { Concern on solid waste management and } \\
\text { readiness to adjust to new practices }\end{array}$ & Bring reusable bag for shopping & (Zen et al., 2013) \\
\hline $\begin{array}{l}\text { Awareness (familiarity to energy-efficient } \\
\text { labels), attitude (standpoint on energy-savings) } \\
\text { and social norms (environmental lifestyles) }\end{array}$ & $\begin{array}{l}\text { Purchasing energy-efficient } \\
\text { products and appliances based on } \\
\text { energy efficiency labels }\end{array}$ & $\begin{array}{l}\text { (Zainudin et al., } \\
\text { 2014) }\end{array}$ \\
\hline $\begin{array}{l}\text { Perceived consumer } \\
\text { (environment related past experience } \\
\text { behaviour, environment-related intention- } \\
\text { behaviour, willingness to pay, and regulatory } \\
\text { support - separating household waste, being a } \\
\text { member of environmental groups }\end{array}$ & $\begin{array}{l}\text { environmentally conscious } \\
\text { consumer behaviour (purchasing } \\
\text { biodegradable products, energy- } \\
\text { saving products, and products that } \\
\text { are less harmful to the } \\
\text { environment) }\end{array}$ & $\begin{array}{l}\text { (Ramly et al., } \\
\text { 2012) }\end{array}$ \\
\hline $\begin{array}{l}\text { Environmental emotions, environmental } \\
\text { cognition (well-informed, understanding and } \\
\text { knowledge on green practices), environmental } \\
\text { attitude (general sense of favourableness or } \\
\text { unfavourableness for green behaviour) }\end{array}$ & $\begin{array}{l}\text { Keeping materials out of the waste } \\
\text { stream: reduce (minimising } \\
\text { consumption), reuse (use again or } \\
\text { repurpose used materials) and } \\
\text { recycle }\end{array}$ & $\begin{array}{l}\text { (Nameghi \& } \\
\text { Shadi, 2013) }\end{array}$ \\
\hline
\end{tabular}

The case studies generated three significant components of AP: (i) Energy Saving (APa), (ii) Waste Handling (APb) and (iii) Smart Consumer (APc). 
PLANNING MALAYSIA

Journal of the Malaysia Institute of Planners (2020)

Table 2 Components and Determinants of Attitude and Pro-Environmental Behaviour

\begin{tabular}{|c|c|c|c|}
\hline Definition of AP & Components & Indicators & Code \\
\hline \multirow{10}{*}{$\begin{array}{l}\text { The positive and } \\
\text { responsible } \\
\text { behaviours } \\
\text { throughout } \\
\text { everyday } \\
\text { decisions and } \\
\text { actions attempted } \\
\text { to favour and } \\
\text { safeguard the } \\
\text { environment }\end{array}$} & \multirow{2}{*}{$\begin{array}{l}\text { Energy } \\
\text { Saving }\end{array}$} & turning off fans and lights when they are switched on & \multirow{2}{*}{$\mathrm{APa}$} \\
\hline & & turning off taps when brushing teeth & \\
\hline & \multirow{4}{*}{$\begin{array}{l}\text { Waste } \\
\text { Handling }\end{array}$} & throwing rubbish according to designated recycle bins & \multirow{4}{*}{$\mathrm{APb}$} \\
\hline & & separating rubbish at home (metals, paper, glass, etc.) & \\
\hline & & reusing grocery bags/ jars/ bottles/ boxes/ cans, etc. & \\
\hline & & using towels instead of tissues & \\
\hline & \multirow{4}{*}{$\begin{array}{l}\text { Smart } \\
\text { Consumer }\end{array}$} & using water tumbler instead of purchasing water & \multirow{4}{*}{$\mathrm{APc}$} \\
\hline & & purchasing refillable detergents & \\
\hline & & purchasing energy-savings appliance & \\
\hline & & purchasing products that are organically produced & \\
\hline
\end{tabular}

Personal Lifestyle (PL) manifests in the personal outlook and approach to life in relation to environmental consciousness (Abu Bakar et al., 2017a, $2017 b, 2017 \mathrm{c}, 2018$ ). Qualities adhere to PL include (i) moral stance in collectivistic values (Laurens, 2012; Clark et al., 2014; Caesar, 2016), (ii) commitment to modest and environmental choices (Horayangkura, 2012; Laurens, 2012; Khare, 2015; Ming et al., 2015), and (iii) environmental concerns through knowledge and awareness (Horayangkura, 2012; Masud et al., 2013; Ming et al., 2015).

Table 3 Determinants of Personal Lifestyle

\begin{tabular}{|c|c|c|}
\hline Definition of PL & Indicators & Code \\
\hline \multirow{10}{*}{$\begin{array}{l}\text { The personal orientation that } \\
\text { portrays collectivistic worldviews, } \\
\text { modesty and humility towards } \\
\text { others as well as consciousness of } \\
\text { environmental issues }\end{array}$} & favouring relationships with others over personal success & PL1 \\
\hline & choosing to disappointing self over disappointing family & PL2 \\
\hline & taking account others' opinions in making life decisions & PL3 \\
\hline & taking the pleasure of working with others & PL4 \\
\hline & practising moderation in purchasing and using resources & PL5 \\
\hline & feeling unconcerned if not being able to afford things & PL6 \\
\hline & believing that having many assets does not lead to happiness & PL7 \\
\hline & being mindful about environmental destruction & PL8 \\
\hline & feeling affected by the environmental loss of other countries & PL9 \\
\hline & urging media to raise environmental awareness & PL10 \\
\hline
\end{tabular}

According to theoretical fundamentals, the research hypothesize that AP components are predictable by PL. The following sections provide empirical evidence on the predictability of $\mathrm{APa}, \mathrm{APb}$ and $\mathrm{APc}$ based on PL items.

\section{METHOD}

A sample of 4315 was pooled and statistically assessed. An 11-point Likert scale was given to the Malaysian respondents to reply to questionnaire items which consist of the components of AP and the ten (10) PL items. Pearson correlation analyses were carried out to determine significant linear associations between the AP components and PL items. The significant correlations warrant for multiple linear regression analyses to estimate parameters of the linear equations in order to predict values of $\mathrm{APa}, \mathrm{APb}$ and $\mathrm{APc}$ from $\mathrm{PL}$ items. 
Aisyah Abu Bakar, Mariana Mohamed Osman, Mizan Hitam

Attitudes and Pro-Environmental Behaviours: Determining Factor of Personality and Lifestyle

\section{RESULTS AND DISCUSSION}

Table 4 Multiple Correlations between PL items and $\mathrm{APa}, \mathrm{APb}$ and $\mathrm{APc}$

\begin{tabular}{|c|c|c|c|c|c|c|c|c|c|c|c|}
\hline $\mathrm{H}_{0}$ & \multicolumn{11}{|c|}{ There is no statistically significant correlation between APa and respective PL items } \\
\hline $\mathrm{H}_{0}$ & \multicolumn{11}{|c|}{ There is no statistically significant correlation between $\mathrm{APb}$ and respective PL items } \\
\hline $\mathrm{H}_{0}$ & \multicolumn{11}{|c|}{ There is no statistically significant correlation between APc and respective PL items } \\
\hline \multicolumn{12}{|c|}{ Correlation Strength Threshold (Dancey \& Riley, 2004) } \\
\hline 0 & .1 & & & 3 & .4 & 5 & .6 & .7 & .8 & .9 & 1 \\
\hline zero & \multicolumn{4}{|c|}{ weak } & \multicolumn{3}{|c|}{ moderate } & \multicolumn{3}{|c|}{ strong } & perfect \\
\hline DV & Stats & PL1 & PL2 & PL3 & PL4 & PL5 & PL6 & PL7 & PL8 & PL9 & PL10 \\
\hline \multirow{3}{*}{$\mathrm{APa}$} & $\mathrm{r}$ & $.339^{* *}$ & $.317^{* *}$ & $.330^{* *}$ & $.380^{* *}$ & $.364^{* *}$ & $.325^{* *}$ & $.294^{* *}$ & $.330^{* *}$ & $.307^{* *}$ & $.392^{* *}$ \\
\hline & $\mathrm{p}$ & .000 & .000 & .000 & .000 & .000 & .000 & .000 & .000 & .000 & .000 \\
\hline & $\mathrm{N}$ & 4315 & 4315 & 4315 & 4315 & 4315 & 4315 & 4315 & 4315 & 4315 & 4315 \\
\hline \multirow{3}{*}{$\mathrm{APb}$} & $\mathrm{r}$ & $.261^{* *}$ & $.259^{* *}$ & $.284^{* *}$ & $.305^{* *}$ & $.302^{* *}$ & $.278^{* *}$ & $.277^{* *}$ & $.301^{* * *}$ & $.254^{* *}$ & $.267^{* *}$ \\
\hline & $\mathrm{p}$ & .000 & .000 & .000 & .000 & .000 & .000 & .000 & .000 & .000 & .000 \\
\hline & $\mathrm{N}$ & 4315 & 4315 & 4315 & 4315 & 4315 & 4315 & 4315 & 4315 & 4315 & 4315 \\
\hline \multirow{3}{*}{$\mathrm{APc}$} & $\mathrm{r}$ & $.313^{* *}$ & $.301^{* *}$ & $.317^{* *}$ & $.370^{* *}$ & $.338^{* *}$ & $.320^{* *}$ & $.312^{* *}$ & $.334^{* *}$ & $.300^{* *}$ & $.341^{* *}$ \\
\hline & $\mathrm{p}$ & .000 & .000 & .000 & .000 & .000 & .000 & .000 & .000 & .000 & .000 \\
\hline & $\mathrm{N}$ & 4315 & 4315 & 4315 & 4315 & 4315 & 4315 & 4315 & 4315 & 4315 & 4315 \\
\hline \multicolumn{12}{|c|}{ Statistical Interpretation of Multiple Correlation Analyses } \\
\hline $\mathrm{APa}$ & \multicolumn{11}{|c|}{$\begin{array}{l}\text { At } 95 \% \text { confidence level, there were statistically significant and weak correlations between APa and } \\
\text { (i) PL1 }(\mathrm{r}=.339, \mathrm{p}=.000) ;(\text { ii) PL2 }(\mathrm{r}=.317, \mathrm{p}=.000) ;(\text { iii) PL3 }(\mathrm{r}=.330, \mathrm{p}=.000) ;(\mathrm{iv}) \text { PL4 ( } \\
=.380, \mathrm{p}=.000) ;(\mathrm{v}) \text { PL5 }(\mathrm{r}=.364, \mathrm{p}=.000) ;(\mathrm{vi}) \text { PL6 }(\mathrm{r}=.325, \mathrm{p}=.000) ;(\mathrm{vii}) \text { PL7 }(\mathrm{r}=.294, \mathrm{p}= \\
.000) ;(\text { viii) PL8 }(\mathrm{r}=.330, \mathrm{p}=.000) ;(\mathrm{ix}) \text { PL9 }(\mathrm{r}=.307, \mathrm{p}=.000) ; \text { and }(\mathrm{x}) \text { PL10 }(\mathrm{r}=.392, \mathrm{p}=.000) \text {. }\end{array}$} \\
\hline $\mathrm{APb}$ & \multicolumn{11}{|c|}{$\begin{array}{l}\text { At 95\% confidence level, there were statistically significant and weak correlations between APb and } \\
\text { (i) PL1 }(\mathrm{r}=.261, \mathrm{p}=.000) ;(\text { ii) PL2 }(\mathrm{r}=.259, \mathrm{p}=.000) ;(\text { iii) PL3 }(\mathrm{r}=.284, \mathrm{p}=.000) ;(\text { iv) PL4 (r } \\
=.305, \mathrm{p}=.000) ;(\mathrm{v}) \text { PL5 }(\mathrm{r}=.302, \mathrm{p}=.000) ;(\mathrm{vi}) \text { PL6 }(\mathrm{r}=.278, \mathrm{p}=.000) ;(\mathrm{vii}) \text { PL7 }(\mathrm{r}=.277, \mathrm{p}= \\
.000) ;(\mathrm{viii}) \text { PL8 }(\mathrm{r}=.301, \mathrm{p}=.000) ;(\mathrm{ix}) \text { PL9 }(\mathrm{r}=.254, \mathrm{p}=.000) ; \text { and }(\mathrm{x}) \text { PL10 }(\mathrm{r}=.267, \mathrm{p}=.000) \text {. }\end{array}$} \\
\hline $\mathrm{APc}$ & \multicolumn{11}{|c|}{$\begin{array}{l}\text { At 95\% confidence level, there were statistically significant and weak correlations between APc and } \\
\text { (i) PL1 }(\mathrm{r}=.313, \mathrm{p}=.000) ;(\text { ii) PL2 }(\mathrm{r}=.301, \mathrm{p}=.000) ;(\text { iii) PL3 }(\mathrm{r}=.317, \mathrm{p}=.000) ;(\mathrm{iv}) \text { PL4 ( } \mathrm{r} \\
=.370, \mathrm{p}=.000) ;(\mathrm{v}) \text { PL5 }(\mathrm{r}=.338, \mathrm{p}=.000) ;(\mathrm{vi}) \text { PL6 }(\mathrm{r}=.320, \mathrm{p}=.000) ;(\mathrm{vii}) \text { PL7 }(\mathrm{r}=.312, \mathrm{p}= \\
.000) ;(\mathrm{viii}) \text { PL8 }(\mathrm{r}=.334, \mathrm{p}=.000) ;(\mathrm{ix}) \text { PL9 }(\mathrm{r}=.300, \mathrm{p}=.000) ; \text { and }(\mathrm{x}) \text { PL10 }(\mathrm{r}=.341, \mathrm{p}=.000) \text {. }\end{array}$} \\
\hline
\end{tabular}

At $95 \%$ confidence level, there were statistically significant positive correlations between (i) APa and each of PL items, (ii) APb and each of PL items, and (iii) APc and each of PL items. The null hypotheses claiming there are no statistically significant correlations between (i) APa and respective PL items, (ii) $\mathrm{APb}$ and respective PL items, and (iii) APc and respective PL items were all rejected.

Three (3) multiple regression analyses were carried out to predict the values of each of dependent variables (i) $\mathrm{APa}$, (ii) $\mathrm{APb}$ and (iii) APc given the set of PL explanatory variables (PL1, PL2, PL3, PL4, PL5, PL6, PL7, PL8, PL9, and PL10). 
PLANNING MALAYSIA

Journal of the Malaysia Institute of Planners (2020)

Table 5 Multiple Linear Regression - PL predicting APa

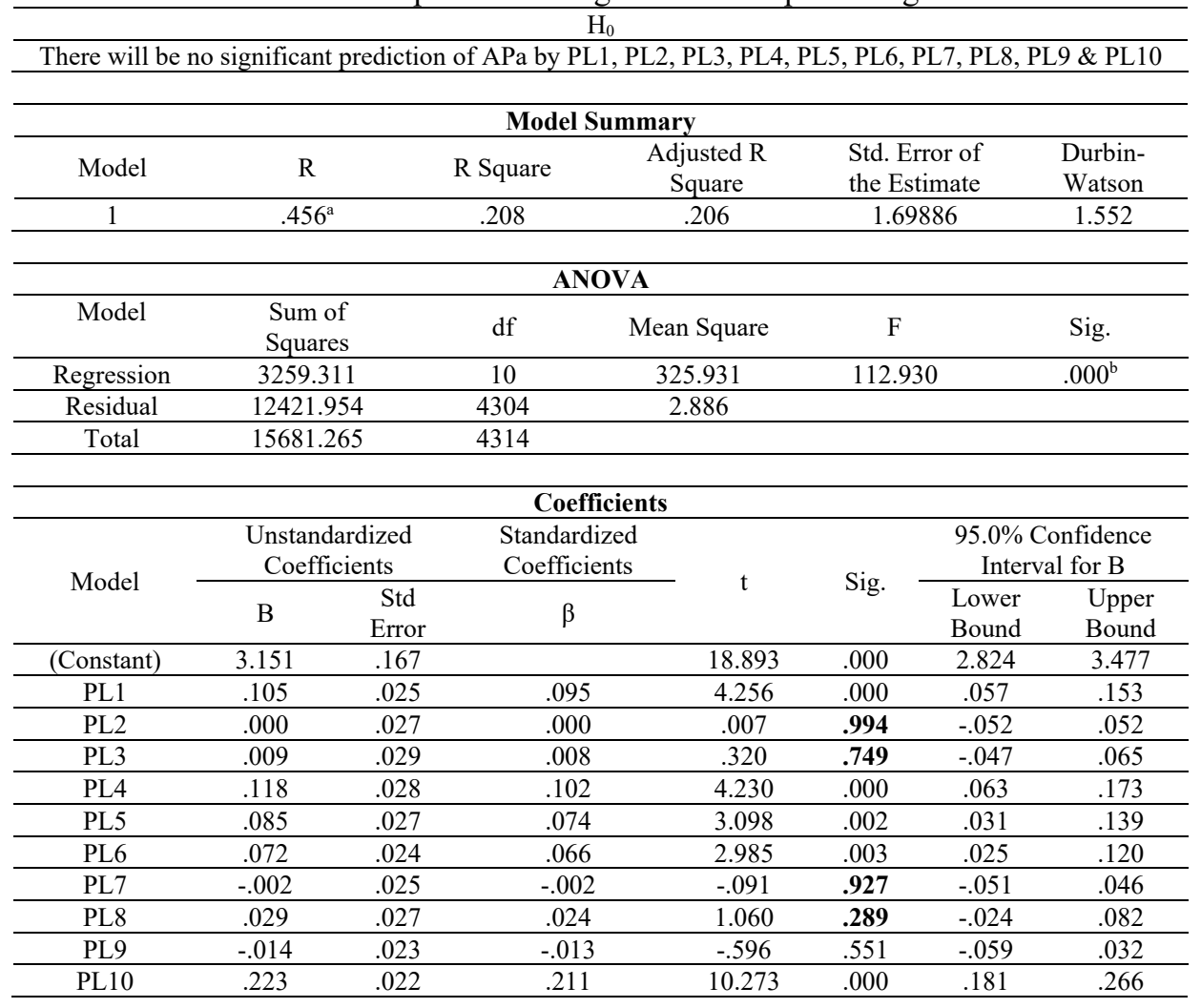

A multiple regression was generated to predict APa based on PL items. $R$ value of .456 indicated an adequate level of prediction $(R>0.4)$. The DurbinWatson statistic was 1.552 which is greater than 1.0 and therefore the data was not autocorrelated. A significant regression equation was found, $F(10,4304)=$ $112.930, \mathrm{p}=.000$, with an $\mathrm{R}^{2}$ of .208 ; indicating that the proportion of variance in APa that can be explained by PL items was $20.8 \%$.

At $95 \%$ confidence level, PL1 $(\mathrm{B}=.105, \mathrm{t}=4.256, \mathrm{p}=.000)$; PL4 (B $=.118, \mathrm{t}=4.23, \mathrm{p}=.000) ;$ PL5 $(\mathrm{B}=.085, \mathrm{t}=3.098, \mathrm{p}=.002) ;$ PL6 $(\mathrm{B}=.072, \mathrm{t}$ $=2.985, \mathrm{p}=.003)$ and PL10 $(\mathrm{B}=.223, \mathrm{t}=1.273, \mathrm{p}=.000)$ were significant predictors of $\mathrm{APa}$. On the contrary, it was found that PL2 $(\mathrm{B}=.000, \mathrm{t}=.007, \mathrm{p}=$ $.994) ;$ PL3 ( $\mathrm{B}=.009, \mathrm{t}=.32, \mathrm{p}=.749) ;$ PL7 ( $\mathrm{B}=-.002, \mathrm{t}=-.091, \mathrm{p}=.927) ;$ PL8 $(\mathrm{B}=.029, \mathrm{t}=1.06, \mathrm{p}=.289)$ and PL9 $(\mathrm{B}=-.014, \mathrm{t}=-.596, \mathrm{p}=.551)$ were not significant predictors of $\mathrm{APa}$.

Personality and Lifestyle (PL) items account for $20.8 \%$ of Energy Saving (APa). Five (5) of PL items were significant predictors of APa. 
Aisyah Abu Bakar, Mariana Mohamed Osman, Mizan Hitam

Attitudes and Pro-Environmental Behaviours: Determining Factor of Personality and Lifestyle

Table 6 Multiple Linear Regression - PL predicting APb

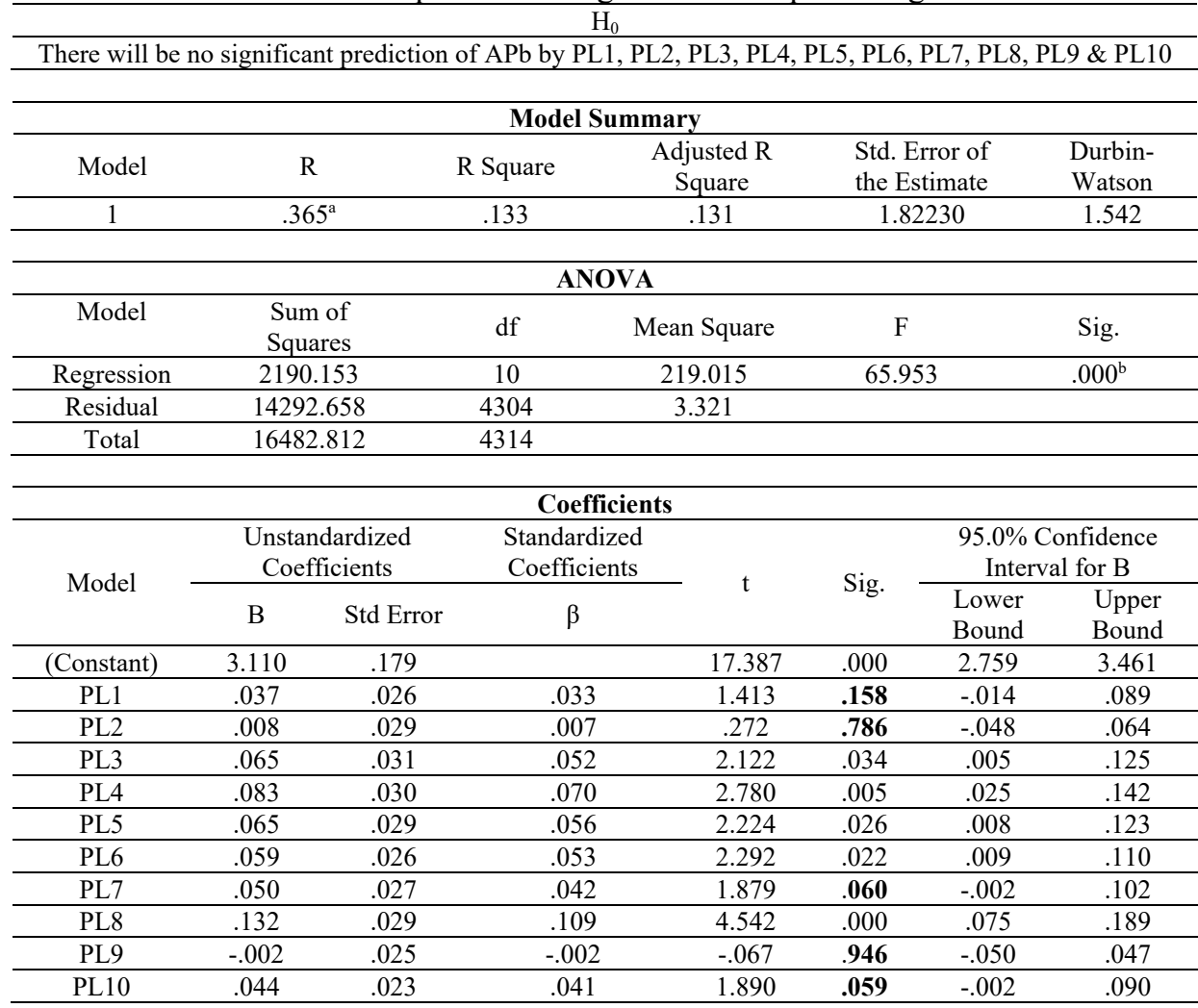

A multiple regression was generated to predict $\mathrm{APb}$ based on PL items. $\mathrm{R}$ value of .365 indicated slightly a weak level of prediction $(\mathrm{R}<0.4)$. The Durbin-Watson statistic was 1.542 which is greater than 1.0 and therefore the data was not autocorrelated. A significant regression equation was found, $F(10,4304)$ $=65.953, \mathrm{p}=.000$, with an $\mathrm{R}^{2}$ of .133 ; indicating that the proportion of variance in $\mathrm{APb}$ that can be explained by PL items was $13.3 \%$.

At $95 \%$ confidence level, PL3 ( $\mathrm{B}=.065, \mathrm{t}=2.122, \mathrm{p}=.034)$; PL4 (B $=.083, \mathrm{t}=2.78, \mathrm{p}=.005) ;$ PL5 $(\mathrm{B}=.065, \mathrm{t}=2.224, \mathrm{p}=.026) ;$ PL6 $(\mathrm{B}=.059, \mathrm{t}$ $=2.292, \mathrm{p}=.022)$ and PL8 $(\mathrm{B}=.132, \mathrm{t}=4.542, \mathrm{p}=.000)$ were significant predictors of $\mathrm{APb}$. On the contrary, it was found that PL1 $(\mathrm{B}=.037, \mathrm{t}=1.413, \mathrm{p}$ $=.158) ;$ PL2 $(\mathrm{B}=.008, \mathrm{t}=.272, \mathrm{p}=.786) ;$ PL7 $(\mathrm{B}=.050, \mathrm{t}=1.879, \mathrm{p}=.060) ;$ PL9 $(\mathrm{B}=-.002, \mathrm{t}=-.067, \mathrm{p}=.946)$ and PL10 $(\mathrm{B}=.044, \mathrm{t}=1.89, \mathrm{p}=.059)$ were not significant predictors of $\mathrm{APb}$.

Personality and Lifestyle (PL) items account for $13.3 \%$ of Waste Handling ( $\mathrm{APb}$ ). Five (5) of PL items were significant predictors of $\mathrm{APb}$. 
PLANNING MALAYSIA

Journal of the Malaysia Institute of Planners (2020)

Table 7 Multiple Linear Regression - PL predicting APC

\begin{tabular}{|c|c|c|c|c|c|c|c|}
\hline \multicolumn{8}{|c|}{$\mathrm{H}_{0}$} \\
\hline \multicolumn{8}{|c|}{ There will be no significant prediction of APc by PL1, PL2, PL3, PL4, PL5, PL6, PL7, PL8, PL9 \& PL10 } \\
\hline \multicolumn{8}{|c|}{ Model Summary } \\
\hline Model & \multicolumn{2}{|c|}{$\mathrm{R}$} & R Square & $\begin{array}{c}\text { Adjusted R } \\
\text { Square }\end{array}$ & \multicolumn{2}{|c|}{$\begin{array}{l}\text { Std. Error of } \\
\text { the Estimate }\end{array}$} & $\begin{array}{l}\text { Durbin- } \\
\text { Watson }\end{array}$ \\
\hline 1 & \multicolumn{2}{|c|}{$.428^{\mathrm{a}}$} & .183 & .181 & \multicolumn{2}{|c|}{1.56634} & 1.532 \\
\hline \multicolumn{8}{|c|}{ ANOVA } \\
\hline Model & \multicolumn{2}{|c|}{$\begin{array}{l}\text { Sum of } \\
\text { Squares }\end{array}$} & df & Mean Square & \multicolumn{2}{|c|}{$\mathrm{F}$} & Sig. \\
\hline Regression & \multicolumn{2}{|c|}{2363.151} & 10 & 236.315 & \multicolumn{2}{|c|}{96.321} & $.000^{\mathrm{b}}$ \\
\hline Residual & \multicolumn{2}{|c|}{10559.512} & 4304 & 2.453 & & & \\
\hline Total & \multicolumn{2}{|c|}{12922.663} & 4314 & & & & \\
\hline \multicolumn{8}{|c|}{ Coefficients } \\
\hline \multirow{2}{*}{ Model } & \multicolumn{2}{|c|}{$\begin{array}{l}\text { Unstandardized } \\
\text { Coefficients }\end{array}$} & $\begin{array}{l}\text { Standardized } \\
\text { Coefficients }\end{array}$ & \multirow{2}{*}{$\mathrm{t}$} & \multirow{2}{*}{ Sig. } & \multicolumn{2}{|c|}{$\begin{array}{l}95.0 \% \text { Confidence } \\
\text { Interval for B }\end{array}$} \\
\hline & B & Std Error & & & & $\begin{array}{l}\text { Lower } \\
\text { Bound }\end{array}$ & $\begin{array}{l}\text { Upper } \\
\text { Bound }\end{array}$ \\
\hline (Constant) & 3.181 & .154 & & 20.690 & .000 & 2.880 & 3.482 \\
\hline PL1 & .066 & .023 & & 2.896 & .004 & .021 & .110 \\
\hline PL2 & .000 & .025 & & .009 & .993 & -.048 & .048 \\
\hline PL3 & .007 & .026 & & .270 & .787 & -.044 & .059 \\
\hline PL4 & .154 & .026 & & 6.005 & .000 & .104 & .205 \\
\hline PL5 & .012 & .025 & & .463 & .643 & -.038 & .061 \\
\hline PL6 & .075 & .022 & & 3.344 & .001 & .031 & .118 \\
\hline PL7 & .053 & .023 & & 2.333 & .020 & .009 & .098 \\
\hline PL8 & .070 & .025 & & 2.787 & .005 & .021 & .119 \\
\hline PL9 & .007 & .021 & & .349 & .727 & -.034 & .049 \\
\hline PL10 & .109 & .020 & & 5.426 & .000 & .069 & .148 \\
\hline
\end{tabular}

A multiple regression was generated to predict APa based on PL items. $R$ value of .428 indicated an adequate level of prediction $(R>0.4)$. The DurbinWatson statistic was 1.532 which is greater than 1.0 and therefore the data was not autocorrelated. A significant regression equation was found, F $(10,4304)=$ $96.321, \mathrm{p}=.000$, with an $\mathrm{R}^{2}$ of .183 ; indicating that the proportion of variance in APc that can be explained by PL items was $18.3 \%$.

At $95 \%$ confidence level, PL1 $(\mathrm{B}=.066, \mathrm{t}=2.896, \mathrm{p}=.004) ;$ PL4 (B $=.154, \mathrm{t}=6.005, \mathrm{p}=.000) ; \operatorname{PL6}(\mathrm{B}=.075, \mathrm{t}=3.344, \mathrm{p}=.001) ; \operatorname{PL} 7(\mathrm{~B}=.053, \mathrm{t}$ $=2.333, \mathrm{p}=.020) ;$ PL8 $(\mathrm{B}=.070, \mathrm{t}=2.787, \mathrm{p}=.005)$ and PL10 $(\mathrm{B}=.109, \mathrm{t}=$ $5.426, \mathrm{p}=.000)$ were significant predictors of APc. On the contrary, it was found that PL2 $(\mathrm{B}=.000, \mathrm{t}=.009, \mathrm{p}=.993) ;$ PL3 $(\mathrm{B}=.007, \mathrm{t}=.27, \mathrm{p}=.787)$; PL5 (B $=.012, \mathrm{t}=.463, \mathrm{p}=.643)$ and PL9 $(\mathrm{B}=.007, \mathrm{t}=.349, \mathrm{p}=.727)$ were not significant predictors of APc.

Personality and Lifestyle (PL) items account for $18.3 \%$ of Smart Consumer (APc). Six (6) of PL items were significant predictors of APc. 
Aisyah Abu Bakar, Mariana Mohamed Osman, Mizan Hitam

Attitudes and Pro-Environmental Behaviours: Determining Factor of Personality and Lifestyle

Table 8 Summary of Findings

\begin{tabular}{|c|c|c|c|c|c|}
\hline & & \multicolumn{4}{|c|}{ IV (Predictor Variables) - $\beta$} \\
\hline & & PL4 & PL5 & PL6 $\quad$ PL7 & PL10 \\
\hline \multirow{3}{*}{$\begin{array}{l}\text { DV } \\
\text { (Outcome } \\
\text { Variables) }\end{array}$} & $\mathrm{APa}$ & $.000 \times .008 \times .102 \checkmark$ & $.074 \checkmark$ & $.066 \checkmark-.002 \times .024 \times-.013 \times$ & $.211 \checkmark$ \\
\hline & $\mathrm{APb}$ & $.033 \times .007 \times .052 \checkmark .070 \checkmark$ & $.056 \sqrt{ }$ & $.053 \checkmark \quad .042 \times \quad .109 \checkmark-.002 X$ & $.041 X$ \\
\hline & APc & $.066 \checkmark .000 \times .006 \times .146 \checkmark$ & $.011 X$ & $.075 \checkmark \quad .050 \checkmark \quad .065 \checkmark \quad .008 X$ & $.113 \checkmark$ \\
\hline \multicolumn{6}{|c|}{$\boldsymbol{V}=$ statistically significant predictor; $\boldsymbol{X}=$ not statistically significant predictor } \\
\hline DV & \multicolumn{2}{|c|}{ Indicators } & IV & Top 3 Strongest Predictors & $\beta$ \\
\hline \multirow{3}{*}{$\begin{array}{l}\text { APa } \\
\text { Energy } \\
\text { Saving }\end{array}$} & \multirow{3}{*}{\multicolumn{2}{|c|}{$\begin{array}{l}\text { - turning off fans and lights when they } \\
\text { are switched on } \\
\text { - } \quad \text { turning off taps when brushing teeth }\end{array}$}} & PL10 & $\begin{array}{l}\text { urging media to raise } \\
\text { environmental awareness }\end{array}$ & .211 \\
\hline & & & PL4 & $\begin{array}{l}\text { taking the pleasure of working } \\
\text { with others }\end{array}$ & .102 \\
\hline & & & PL1 & $\begin{array}{l}\text { favouring relationships with } \\
\text { others over personal success }\end{array}$ & .095 \\
\hline \multirow{3}{*}{$\begin{array}{c}\text { APb } \\
\text { Waste } \\
\text { Handling }\end{array}$} & \multirow{3}{*}{\multicolumn{2}{|c|}{ 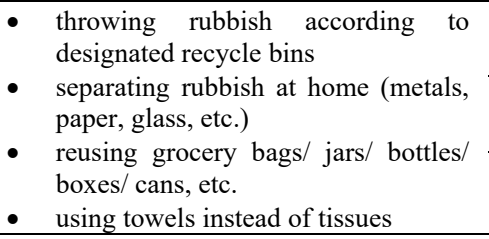 }} & PL8 & $\begin{array}{l}\text { being mindful about } \\
\text { environmental destruction }\end{array}$ & .109 \\
\hline & & & PL4 & $\begin{array}{l}\text { taking the pleasure of working } \\
\text { with others }\end{array}$ & .070 \\
\hline & & & PL5 & $\begin{array}{l}\text { practising moderation in } \\
\text { purchasing and using resources }\end{array}$ & .056 \\
\hline \multirow{3}{*}{$\begin{array}{l}\text { APc } \\
\text { Smart } \\
\text { Consumer }\end{array}$} & \multirow{3}{*}{\multicolumn{2}{|c|}{$\begin{array}{l}\text { - using water tumbler instead of } \\
\text { - } \text { purchasing water } \\
\text { - } \text { purchasing refillable detergents } \\
\text { - } \begin{array}{l}\text { purchasing energy-savings appliance } \\
\text { organically produced }\end{array}\end{array}$}} & PL10 & $\begin{array}{l}\text { urging media to raise } \\
\text { environmental awareness }\end{array}$ & .113 \\
\hline & & & PL1 & $\begin{array}{l}\text { favouring relationships with } \\
\text { others over personal success }\end{array}$ & .075 \\
\hline & & & PL6 & $\begin{array}{l}\text { feeling unconcerned if not } \\
\text { being able to afford things }\end{array}$ & .066 \\
\hline
\end{tabular}

Findings show that PL10, designating 'urging media to raise more environmental awareness' was the strongest predictors of APa and APc. PL8, denoting 'being mindful about environmental destruction' was the strongest predictor for $\mathrm{APb}$. Environmental concerns through mindfulness, awareness and responsiveness are influential in determining environmentally responsible behaviours. On this basis, environmental education that allows individuals to delve into environmental issues, learn to resolve environmental challenges, and take action independently and collectively to improve the environment is crucial. Exposure from the education develops the skills, commitment and eventually habits of making informed and responsible decisions for the environment.

\section{CONCLUSION}

HIE in SSWB suggests that moral concerns explain environmental behaviours. This paper evidence that AP is moderately predictable by PL. In future work, statistical modelling on the constructs elaborated in this paper, along with cultural and economic background intervention, shall prove the research's importance. 
PLANNING MALAYSIA

Journal of the Malaysia Institute of Planners (2020)

\section{ACKNOWLEDGEMENT}

This research was supported by Post-Doctoral Fellow under Research Initatives Grant Scheme (RIGS-PDF), International Islamic University Malaysia (project title: RPDF19-005-0015)

\section{REFERENCES}

Abu Bakar, A., Mohamed Osman, M., Bachok, M., Hitam, M., and Abdullah, A. (2018). Human Interdependency for Sustainable Well-Being: Structural Invariance across Settlement Areas. Planning Malaysia: Journal of the Malaysian Institute of Planners. 16(1) pp. 281-293.

Abu Bakar, A., Mohamed Osman, M., Bachok, S., Ibrahim, M., Abdullah, A., and Abdullah, F. (2017a). A Review on Sustainable Wellbeing Indicators for Human Interrelationships with the Environment. Planning Malaysia: Journal of the Malaysian Institute of Planners, 15 (1). pp. 357-368. ISSN 1675-6215.

Abu Bakar, A., Mohamed Osman, M., Bachok, S., Ibrahim, M., Abdullah, A., and Abdullah, F. (2017b). A theoretical assessment on sustainable wellbeing indicators for people interrelationships. Planning Malaysia: Journal of the Malaysian Institute of Planners, pp. 21-30. ISSN 1675-6215.

Abu Bakar, A., Mohamed Osman, M., Bachok, S., Ibrahim, M., and Abdullah, A. (2017c). Sustainable Well-Being: An Empirical Exploration on Human Interdependence with the Environment. Advanced Science Letters. American Scientific Publishers. 23(7) pp. 6352-6356.

Caesar, L. A. Y. (2016). Performance Excellence by Transformational Leadership in Developing Collectivistic Culture for Indonesian Companies. Pertanika Journal of Social Sciences and Humanities, 24(May), 19-32.

Clark, M., Amar-Singh, H. S., \& Hashim, L. (2014). The Subjective Well-Being of Malaysian School Children: Grade Level, Gender and Ethnicity. Psychology, 5(5), $1453-1462$.

Dancey, C. and Reidy, J. (2004) Statistics without Maths for Psychology: using SPSS for Windows. Prentice Hall, London.

Harizan, S. H. M., Haron, M. S., \& Wahid, N. A. (2013). Islam, Eco-literacy and Green Purchase: Evidence from Malaysia. Journal of Islamic Business and Management, 3(1), 133-149.

Horayangkura, V. (2012). Incorporating Environment-Behavior Knowledge into the Design Process: An Elusive Challenge for Architects in the 21st Century. Procedia - Social and Behavioral Sciences, 50(July 2012), 30-41.

Khare, A. (2015). Influence of Materialism and Money Attitudes on Credit Card Use. International Business Competition and Growth, 4(2), 57-77.

Latif, S. A., \& Omar, M. S. (2012). Determinants of Recycling Behaviour in Tioman Island. Journal of Asian Behavioral Studies, 2(April 2012), 39-50.

Laurens, J. M. (2012). Intervention Program to Change the Pro-environmental Behavior of the Riverside Community. Journal of ASIAN Behavioural Studies, 2(January 2012), 45-56. 
Aisyah Abu Bakar, Mariana Mohamed Osman, Mizan Hitam

Attitudes and Pro-Environmental Behaviours: Determining Factor of Personality and Lifestyle

Masud, M. M., Akhtar, R., Afroz, R., Al-Amin, A. Q., \& Kari, F. B. (2013). Proenvironmental behavior and public understanding of climate change. Mitigation and Adaptation Strategies for Global Change, (June), 1-10.

Ming, B. H., Gan, G. G. G., \& Ramasamy, S. (2015). The Role of Concern for the Environment and Perceived Consumer Effectiveness on Investors' Willingness to Invest in Environmental-Friendly Firms. Kajian Malaysia, 33(1), 173-190.

Nameghi, E. N. M., \& Shadi, M. A. (2013). Affective and Cognitive: Consumers Attitude toward Practicing Green (Reducing, Recycling \& Reusing). International Journal of Marketing Studies, 5(1), 157-164.

Ramly, Z., Hashim, N. H., Yahya, W. K., \& Mohamad, S. A. (2012). Environmentally Conscious Behavior among Malaysian Consumers: An Empirical Analysis. Jurnal Pengurusan, 35, 111-121.

Teng, P. K., Rezai, G., Mohamed, Z., \& Shamsudin, M. N. (2011). Consumers' Intention to Purchase Green Foods in Malaysia. International Conference on Innovation, Management and Service, 14, 112-118.

Zainudin, N., Siwar, C., Choy, E. A., \& Chamhuri, N. (2014). Evaluating the Role of Energy Efficiency Label on Consumers' Purchasing Behaviour. APCBEE Procedia, 10, 326-330.

Zen, I. S., Ahamad, R., \& Omar, W. (2013). No plastic bag campaign day in Malaysia and the policy implication. Environment, Development and Sustainability, 15(5), 1259-1269.

Zena, I. S., Noor, Z. Z., \& Yusuf, R. O. (2014). The profiles of household solid waste recyclers and non-recyclers in Kuala Lumpur, Malaysia. Habitat International, 42, $1-7$ 